\title{
Eyeing the brain
}

\author{
M. Francesca Cordeiro ${ }^{1,2,3}$
}

Published online: 15 October 2016

(C) The Author(s) 2016. This article is published with open access at Springerlink.com

The involvement of the retina in CNS disease is increasingly recognized in the area of neurodegeneration, as there is accumulating evidence showing that similar mechanisms occur in the eye and the brain. These neuropathological processes ultimately lead to neuronal cell death and include ischaemia, inflammation, mitochondrial dysfunction
Fig. 1 Examples of neurodegenerative eye and brain diseases illustrating overlap of key neuropathological mechanisms

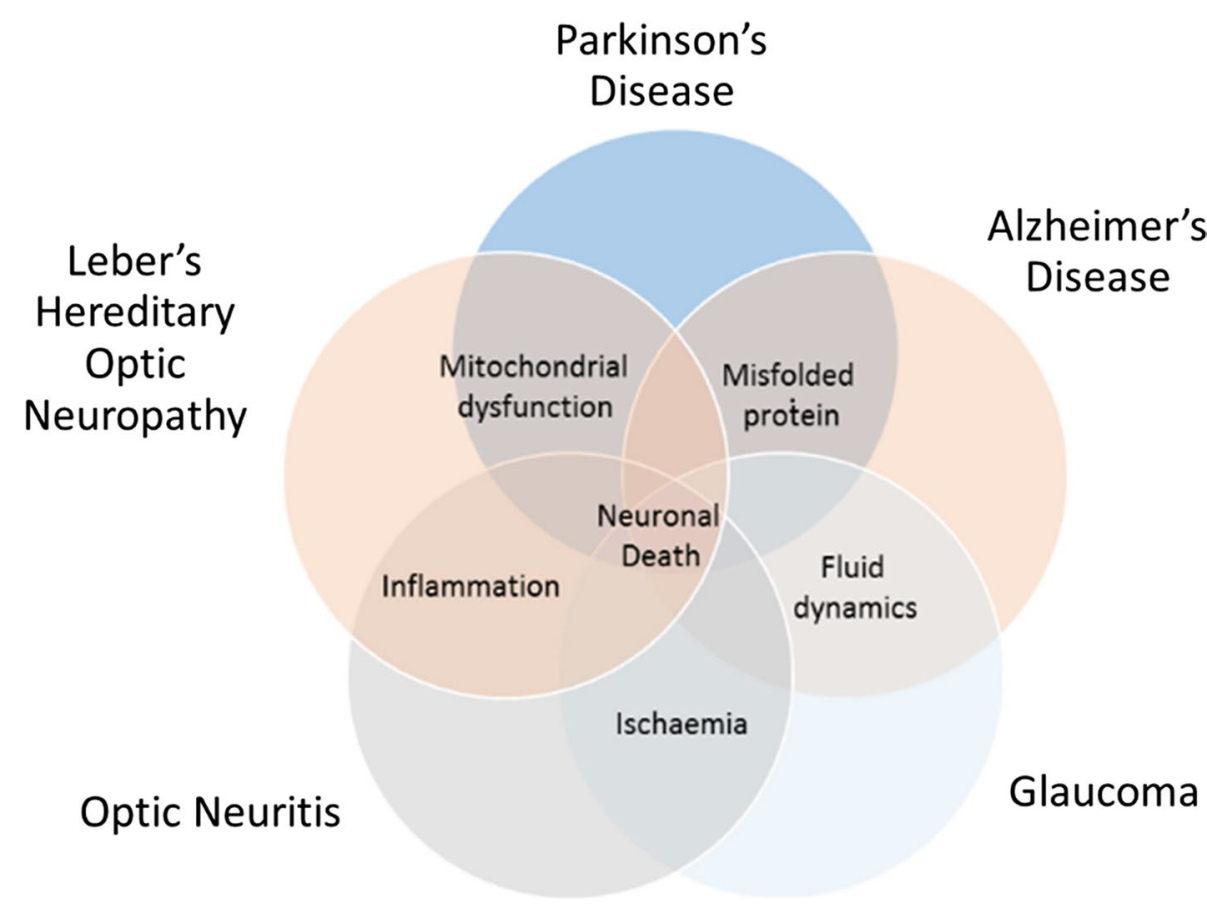

M. Francesca Cordeiro m.cordeiro@ucl.ac.uk

1 Institute of Ophthalmology, UCL Institute of Ophthalmology, 11-43 Bath Street, London EC1V 9EL, UK

2 ICORG, Imperial College London, London, UK

3 Imperial College NHS Trust, Western Eye Hospital, London, UK 
(including oxidative stress), deposition of misfolded proteins, and changes in fluid dynamics [aqueous and cerebrospinal fluid (CSF)] [1, 5, 6, 9-11].

Although common to some degree in all neurodegenerative conditions, specific events are associated more closely with certain diseases. Hence, deposition and aggregation of the misfolded proteins alpha-synuclein and beta-amyloid are believed to be key in their development in Parkinson's disease (PD) and Alzheimer's disease (AD), respectively [4]; mitochondrial dysfunction is particularly associated with LHON (Leber's Hereditary optic neuropathy) and PD [12]; an important element of optic neuritis and LHON is inflammation [2, 14]; both optic neuritis and glaucoma include an ischemic aetiology [3, 8]; and finally, abnormal fluid dynamics is heavily implicated in glaucoma (through intraocular pressure) [3] and AD (CSF clearance) [7]. These overlaps are illustrated in the Venn diagram above (Fig. 1).

This issue of Acta Neuropathologica includes a cluster of three review papers on different aspects of neurodegeneration involving the retina, from experts in ophthalmology, neuro-ophthalmology, and neuroscience and covering glaucoma [3], Alzheimer's disease [7], and LHON [13]. In each case, they address the neuropathological mechanisms that highlight why the retina may serve as a valuable model to study brain disease. They include molecular advances, evidence for commonalities between brain and eye changes, cell death processes, and recent updates on targets for therapy. Furthermore, they promote the idea that due to its accessibility, the eye can be a tool through which disease activity and treatment response can be assessed with widespread applications for neurological disease. This cluster will hopefully be of interest to neuropathologists, ophthalmic pathologists, neuroscientists, and neurologists intrigued by how and why it might be possible to eye the brain.

Acknowledgments The author acknowledges the Wellcome Trust for supporting research in the group for providing the funds.

Open Access This article is distributed under the terms of the Creative Commons Attribution 4.0 International License (http://creativecommons.org/licenses/by/4.0/), which permits unrestricted use, distribution, and reproduction in any medium, provided you give appropriate credit to the original author(s) and the source, provide a link to the Creative Commons license, and indicate if changes were made.

\section{References}

1. Cordeiro MF, Guo L, Luong V, Harding G, Wang W, Jones HE, Moss SE, Sillito AM, Fitzke FW (2004) Real-time imaging of single nerve cell apoptosis in retinal neurodegeneration. Proc Natl Acad Sci USA 101:13352-13356

2. Costello F (2014) Inflammatory optic neuropathies. Continuum (Minneap Minn) 20:816-837. doi:10.1212/01. CON.0000453316.60013.52

3. Davis BM, Crawley L, Pahlitzsch M, Javaid F, Cordeiro MF (2016) Glaucoma: the retina and beyond. Acta Neuropathol. doi:10.1007/s00401-016-1609-2

4. Dobson CM (2003) Protein folding and misfolding. Nature 426:884-890. doi:10.1038/nature02261

5. Favaloro B, Allocati N, Graziano V, Di Ilio C, De Laurenzi V (2012) Role of apoptosis in disease. Aging (Albany NY) 4:330 349. doi:10.18632/aging. 100459

6. Guo L, Salt TE, Luong V, Wood N, Cheung W, Maass A, Ferrari G, Russo-Marie F, Sillito AM, Cheetham ME et al (2007) Targeting amyloid-beta in glaucoma treatment. Proc Natl Acad Sci USA 104:13444-13449. doi:10.1073/pnas.0703707104

7. Hart NJ, Koronyo Y, Black KL, Koronyo-Hamaoui M (2016) Ocular indicators of Alzheimer's: exploring disease in the retina. Acta Neuropathol. doi:10.1007/s00401-016-1613-6

8. Kelley RE (2006) Ischemic demyelination. Neurol Res 28:334340. doi:10.1179/016164106X98242

9. London A, Benhar I, Schwartz M (2013) The retina as a window to the brain-from eye research to CNS disorders. Nat Rev Neurol 9:44-53. doi:10.1038/nrneurol.2012.227

10. Mattson MP (2000) Apoptosis in neurodegenerative disorders. Nat Rev Mol Cell Biol 1:120-129. doi:10.1038/35040009

11. Normando EM, Davis BM, De Groef L, Nizari S, Turner LA, Ravindran N, Pahlitzsch M, Brenton J, Malaguarnera G, Guo L et al (2016) The retina as an early biomarker of neurodegeneration in a rotenone-induced model of Parkinson's disease: evidence for a neuroprotective effect of rosiglitazone in the eye and brain. Acta Neuropathol Commun 4:86. doi:10.1186/ s40478-016-0346-Z

12. Valero $T$ (2014) Mitochondrial biogenesis: pharmacological approaches. Curr Pharm Des 20:5507-5509

13. Yu-Wai-Man P, Votruba M, Burte F, La Morgia C, Barboni P, Carelli V (2016) A neurodegenerative perspective on mitochondrial optic neuropathies. Acta Neuropathol. doi:10.1007/ s00401-016-1625-2

14. Yu AK, Song L, Murray KD, van der List D, Sun C, Shen Y, Xia Z, Cortopassi GA (2015) Mitochondrial complex I deficiency leads to inflammation and retinal ganglion cell death in the Ndufs4 mouse. Hum Mol Genet 24:2848-2860. doi:10.1093/ hmg/ddv045 